\title{
Silicon Dioxide
}

National Cancer Institute

\section{Source}

National Cancer Institute. Silicon Dioxide. NCI Thesaurus. Code C29853.

A natural compound of silicon and oxygen found mostly in sand, Silica has three main crystalline varieties: quartz, tridymite, and cristobalite. Fine particulate silica dust from quartz rock causes over a long-term progressive lung injury, silicosis. ( $\mathrm{NCI04)}$ 